\title{
Life-history traits of non-native freshwater fish invaders differentiate them from natives in the Central European bioregion
}

\author{
Joanna Grabowska • Mirosław Przybylski
}

Received: 8 January 2014/Accepted: 3 November 2014/Published online: 13 November 2014

(C) The Author(s) 2014. This article is published with open access at Springerlink.com

\begin{abstract}
The most successful and widespread nonindigenous invasive fish species occurring in the Central European bioregion are heterogeneous with respect to their origins, taxonomy, mode of arrival, vectors and pathways of dispersal. We surveyed whether these non-native species have common lifehistory that might facilitate their invasion and differentiate them from native species. Ten life-history traits of 59 freshwater fish species were examined: maximum body length, longevity, age and length at maturation, maximum absolute fecundity, egg size, larval size at hatching, spawning duration and type, parental investment. Principal Component Analysis revealed that the traits that accounted for the first two principle components ( $86.4 \%$ of total variation) were maximum body length, age and size at maturation, longevity, fecundity, egg size and larval length at hatching. Five groups of species were distinguished by cluster analysis, those comprising native fish species being characterized by medium-to-large size, elevated longevity, late maturation, high fecundity, and no parental care. In contrast, groups of non-native invasive fish species were characterized by small-tomedium body length, short longevity, early maturation, relatively low fecundity, relatively large eggs, multiple spawning, extended reproductive seasons and
\end{abstract}

J. Grabowska $(\bowtie) \cdot$ M. Przybylski

Department of Ecology and Vertebrate Zoology,

University of Lodz, Banacha 12/16, 90-237 Lodz, Poland

e-mail: joko@biol.uni.lodz.pl some form of parental care. These life-history traits, along with broad diet breath and environmental tolerance, appear to facilitate the invasion of freshwater fish in the Central European bioregion.

Keywords Non-indigenous fishes - Reproduction · Parental care Invasion

\section{Introduction}

An important aspect of invasion biology is the study and predictions of attributes that facilitate biological invasions (e.g. Ehrlich 1989; Williamson 1996; Kolar and Lodge 2001, 2002; Olden et al. 2006; GarciaBerthou 2007; Ribeiro et al. 2007), with life-history traits being of particular interest. It is impossible to identify a single universal model of life history that would guarantee invasive success, i.e. propagule pressure, establishment, dispersal and population growth in a newly colonized area, since it likely depend on multiple factors (Williamson 1999; Kolar and Lodge 2001; Sakai et al. 2001). In addition, success or failure of an introduction event depends not only on the biological attributes of the invader but also on the recipient habitat characteristics, including both biotic and abiotic factors (Brown 1989; Moyle and Light 1996; Williamson 1996; Sakai et al. 2001). A global literature review by Jeschke et al. (2012) revealed that among several hypotheses that 
considered interactions of exotic invaders with their new environment, three of these, i.e. invasional meltdown, novel weapons, and enemy release, are better supported by empirical evidence than other hypotheses (biotic resistance, island susceptibility, tens rule). The novel weapons hypothesis assumes that in the exotic habitat, invasive species can have a competitive advantage against native species because they possess a novel weapon, i.e. a trait that is new to the resident community of native species and, therefore, affects them negatively (Callaway and Ridenour 2004).

Many other historical and contemporary theories of invasion success share the prediction that successful invaders are different from native species in at least in one ecological aspect this is especially well documented for plants (e.g. MacArthur and Wilson 1967; Deahler 2003; MacDougall et al. 2009). In such a situation, the non-native species takes advantage of a so-called 'fitness difference' as defined by MacDougall et al. (2009), i.e. species attributes distinguishing the invader from the natives occupying a similar niche and driving its competitive dominance in the novel ecosystem. Likewise, a revision of invasive fish characteristics implied that introduced species are often quite different from natives (Garcia-Berthou 2007).

Freshwater fish faunas appear particularly susceptible to deliberate introductions (Casal 2006). Further, traits of many non-native fish species result from human choice of species with particular desirable attributes (e.g. large body-size of commercial and game fish) and/or guarantee of successful introduction (e.g. high ecological tolerance of harsh environmental conditions; Alcaraz et al. 2005). However, there is a growing group of invasive fish species that have been introduced unintentionally; hence their biological attributes are not directly biased by human choice. There are several difficulties in identifying the biological attributes that can be used to predict the invasive potential of an introduced fish species. Fish are known to have high phenotypic plasticity (Wooton 1990), with plasticity of their life-history traits more important for invasion success than their genetic variation (Valiente et al. 2010). Life histories may be modified as the population passes through a series of stages of invasion (Bøhn et al. 2004; Fox et al. 2007; Britton et al. 2008; Brandner et al. 2013b), with different traits important during distinct stages of the invasion process (Ribeiro et al. 2007). The suitability of a particular strategy of an invader may vary depending on the local environmental conditions (e.g. Villeneuve et al. 2005; Fox et al. 2007; Kováč et al. 2009; Záhorská and Kováč 2009). Similarly, lifehistory traits displayed by indigenous fish are a tradeoff between the evolutionary heritage of populations and the constraints posed by the environment (Reynolds et al. 2005; Blank et al. 2007). Thus, they are likely to be divergent from traits of species that evolved in different parts of the world.

Based on fish faunistic lists, seven main bioregions were defined for European freshwater fish (Reyjol et al. 2007). One of them, the Central European bioregion, consists of drainages from the R. Elbe on the west, through the Rivers Oder, Vistula, Neman to Narva on the east, as well as of Swedish and Finnish Baltic river systems. This region is characterized by a highly homogenous fauna, rather low species richness, and the lowest level of endemism when compared with other European bioregions (Reyjol et al. 2007), arising from geomorphological alteration of the main river systems in the Pleistocene. As a result the freshwater fauna of this area is relatively young, finally forming about 12,000 years ago after the end of the last glacial period. It is composed mainly of species that recolonised inland waters from the Ponto-Caspian refugium (Bănărescu 1990; Hewitt 2004). This refugium had some importance for the formation of fish fauna in three other biogeographical regions grouped by Reyjol et al. (2007) into 'the Danubian Europe' with this fish fauna different from the so-called 'Peri-Meditteranea' group of biogeographical regions.

The comparisons of life-history traits of non-native versus native fish species occurring in European inland waters have already been completed for Catalonian streams (Vila-Gispert et al. 2005), Iberian Peninsula (Ribeiro et al. 2007) and the River Danube (Erös 2005). Teletchea et al. (2009) proposed a typology for freshwater species living in Western Europe based on the analysis of their reproductive traits, as a framework for the future domestication of other fish species. However, such an analysis and comparison of native and invasive fish fauna life-history traits has never been conducted for the Central European biogeographical region, the second largest region identified by Reyjol et al. (2007).

Taking into account the geographical position of Poland and its hydrological system, it offers a good 
model for the analysis of life-history traits of fish species in the Central European biogeographical region sensu Reyjol et al. (2007). At present, 52 autochthonous fish species and sub-species plus four lampreys occur in Polish inland waters (Witkowski et al. 2004). Additionally, 26 exotic species were recorded as acclimatized, casual or naturalized in Poland and 19 of them live permanently in the wild, constituting $24 \%$ of the country's freshwater fish fauna (Grabowska et al. 2010; Witkowski and Grabowska 2012). Some of these species depend on stocking, while only 11 species have established self-sustained populations in the wild and among those, seven have never been introduced intentionally. Thus, this group of non-native species naturalized in Poland is heterogeneous with respect to its origins, taxonomy, and mode of arrival, vectors and pathways of dispersal. This situation raises the question of whether such a diverse set of non-native species share some biological features that differentiate them from natives and that may contribute to their invasion success. To answer this question the following aims were defined: (1) to identify patterns of life-history traits of native and non-native freshwater fish species in the Central European bioregion; (2) to identify biological attributes that distinguish non-native invasive species from native ones; and (3) to discuss if such differences may facilitate invasive success.

\section{Materials and methods}

Life-history traits of 59 freshwater fish species (Table 1), both native and non-indigenous, occurring in Poland and in other Central European countries were examined. Data were obtained from the main works summarizing information on the freshwater fishes occurring in Poland (Brylińska 2000; Rolik and Rembiszewski 1987). If the necessary details were absent from these sources, we obtained them from other sources (see Table 1). Some native but rare species for which limited data are available for Polish inland waters (e.g. Kessler's gudgeon Romanogobio kessleri, swamp minnow Rhynchocypris percnurus, Peloponnese barbel Barbus peloponnesius, Barbus cyclolepis) were excluded from the analysis. Considering non-native fishes, we omitted species that do not breed in natural conditions in Poland (e.g. Asian cyprinids grass carp Ctenopharyngodon idella, silver carp Hypophthalmichthys molitrix, bighead carp Hypophthalmichthys nobilis and acipenserids) (Grabowska et al. 2010) except for two: rainbow trout Oncorhynus mykiss and common carp Cyprinus carpio, which are the most often widely introduced and abundant commercial species.

Ten life-history traits were considered: (1) maximum body length ( $\mathrm{mm})$; (2) longevity, i.e. maximum age (in years); (3) age at maturation (in years); (4) total length at maturation $(\mathrm{mm})$; (5) maximum absolute fecundity; (6) maximum egg diameter (of fully developed ovaries; mm); (7) larval standard length at hatching $(\mathrm{mm})$; (8) duration of spawning (in months); (9) spawning type-number of spawning events per year $(1=$ single spawning event per year, $2=$ from two-to-four spawning events per year); (10) parental investment as per Balon (1990) re-described from Kryzhanovskii (1949): 1 = non-guarders-open substratum choosers, $2=$ non-guarders-brood hiders (including ostracophils), 3 = guarders—substratum choosers, 4 = guarders - nest spawners, scores given as in Erös (2005). We used averaged values of traits except for those which required a maximum value, e.g. traits number 1, 2, 5 and 6. Whenever maturation and growth data were reported for the sexes separately, we used estimates for females (Winemiller and Rose 1992; Vila-Gispert et al. 2005; Erős 2005). For all analyses, data were $\log (x+1)$ transformed to achieve compliance with the normality assumption except for three traits: reproductive span, spawning type and parental investment which are discrete variables.

Bivariate relationships among life-history traits were analyzed using a Pearson rank correlation coefficient. Principal Component Analysis (PCA) of the seven log-transformed traits was undertaken to reveal patterns of association in the life-history attributes of 59 fish species. To distinguish groups of fish species sharing a common set of life-history traits, cluster analysis (Ward method and Euclidean distances) was used, with the mean PC1 and PC2 scores for distinguished fish groups compared using analysis of variance (ANOVA), followed by multiple comparisons (Tukey-Kramer HDS test), to investigate the sources of variation in life-history traits among fish species. Reproductive span, spawning type and parental investment we compared among distinguished groups with a Kruskal-Wallis test followed by multiple comparisons (Tukey test). All statistical analyses were performed using Statistica 6 (StatSoft Inc 2001). 
Table 1 List of 59 freshwater fish species included in the analysis

\begin{tabular}{|c|c|c|c|c|c|c|}
\hline & Scientific name & Common name & Code & Status & Group & References \\
\hline Anguillidae & Anguilla anguilla & European eel & ANANG & $\mathrm{N}$ & D1 & $\mathrm{A}, \mathrm{E}, \mathrm{F}$ \\
\hline \multirow[t]{26}{*}{ Cyprinidae } & Barbus barbus & European barbel & BRBAR & $\mathrm{N}$ & D1 & $\mathrm{A}, \mathrm{B}, \mathrm{C}, \mathrm{D}, \mathrm{E}$ \\
\hline & 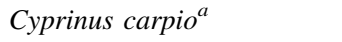 & Common carp & CYCAR & $\mathrm{E}$ & D1 & $\mathrm{A}, \mathrm{C}, \mathrm{E}$ \\
\hline & Carassius carassius & Crucian carp & CACAR & $\mathrm{N}$ & D1 & $\mathrm{A}, \mathrm{C}, \mathrm{S}$ \\
\hline & Carassius gibelio & Gibel carp & CAAUR & $\mathrm{E}$ & D1 & $\mathrm{A}, \mathrm{C}, \mathrm{S}$ \\
\hline & Gobio gobio & Gudgeon & GOGOB & $\mathrm{N}$ & B & $\mathrm{A}, \mathrm{C}, \mathrm{D}$ \\
\hline & Gobio albipinnatus & White-finned gudgeon & GOALB & $\mathrm{N}$ & B & $\mathrm{C}, \mathrm{E}, \mathrm{A}$ \\
\hline & Tinca tinca & Tench & TITIN & $\mathrm{N}$ & D1 & $\mathrm{A}, \mathrm{B}, \mathrm{C}, \mathrm{D}$ \\
\hline & Rhodeus amarus & European bitterling & ROSER & $\mathrm{N}$ & A & $\mathrm{A}, \mathrm{B}$ \\
\hline & Abramis brama & Common bream & ABBRA & $\mathrm{N}$ & D1 & $\mathrm{A}, \mathrm{C}$ \\
\hline & Abramis bjoerkna & Silver bream & ABBJO & $\mathrm{N}$ & D1 & $\mathrm{A}, \mathrm{C}, \mathrm{D}$ \\
\hline & Abramis ballerus & Blue bream & ABBAL & $\mathrm{N}$ & D2 & $\mathrm{A}, \mathrm{D}, \mathrm{B}$ \\
\hline & Abramis sapa & White-eye bream & ABSAP & $\mathrm{N}$ & D2 & A \\
\hline & Vimba vimba & Vimba & VIVIM & $\mathrm{N}$ & D1 & A, C, D \\
\hline & Rutilus rutilus & Roach & RURUT & $\mathrm{N}$ & D2 & $\mathrm{A}, \mathrm{B}, \mathrm{C}$ \\
\hline & Scardinius erythrophtalmus & Rudd & SCERY & $\mathrm{N}$ & D2 & $\mathrm{A}, \mathrm{E}$ \\
\hline & Chondrostoma nasus & Nase & CHNAS & $\mathrm{N}$ & D2 & $\mathrm{A}, \mathrm{C}, \mathrm{E}$ \\
\hline & Aspius aspius & Asp & ASASP & $\mathrm{N}$ & D1 & A \\
\hline & Leucaspius delineatus & Sunbleak & LEDEL & $\mathrm{N}$ & A & $\mathrm{A}, \mathrm{C}, \mathrm{B}, \mathrm{E}$ \\
\hline & Phoxinus phoxinus & European minnow & PHPHO & $\mathrm{N}$ & B & $\mathrm{A}, \mathrm{B}, \mathrm{C}$ \\
\hline & Leuciscus leuciscus & Dace & LELEU & $\mathrm{N}$ & D2 & A, B \\
\hline & Leuciscus idus & Ide & LEIDU & $\mathrm{N}$ & D2 & $\mathrm{A}, \mathrm{C}, \mathrm{I}$ \\
\hline & Leuciscus cephalus & Chub & LECEP & $\mathrm{N}$ & D1 & $\mathrm{A}, \mathrm{D}$ \\
\hline & Pelecus cultratus & Sichel & PECUL & $\mathrm{N}$ & D2 & A \\
\hline & Alburnus alburnus & Bleak & ALALB & $\mathrm{N}$ & B & $\mathrm{A}, \mathrm{C}$ \\
\hline & Alburnoides bipunctatus & Spirlin & ALBIP & $\mathrm{N}$ & B & A, B, E, D \\
\hline & Pseudorasbora parva & Topmouth gudgeon & PSPAR & $\mathrm{E}$ & A & $\mathrm{A}, \mathrm{G}$ \\
\hline \multirow[t]{3}{*}{ Cobitidae } & Cobitis taenia & Spined loach & COTAE & $\mathrm{N}$ & B & $\mathrm{A}, \mathrm{H}$ \\
\hline & Sabanejewia aurata & Golden loach & SAAUR & $\mathrm{N}$ & B & $\mathrm{A}, \mathrm{H}$ \\
\hline & Misgurnus fossilis & Weatherfish & MIFOS & $\mathrm{N}$ & D1 & $\mathrm{A}, \mathrm{B}, \mathrm{F}, \mathrm{E}, \mathrm{H}$ \\
\hline Balitoridae & Barbatula barbatula & Stone loach & BABAR & $\mathrm{N}$ & B & $\mathrm{A}, \mathrm{H}$ \\
\hline Ictaluridae & Ameiurus nebulosus & Brown bullhead & AMNEB & $\mathrm{E}$ & A & $\mathrm{A}, \mathrm{C}, \mathrm{B}, \mathrm{N}$ \\
\hline Siluridae & Silurus glanis & European catfish & SIGLA & $\mathrm{N}$ & $\mathrm{C}$ & A,D \\
\hline Esocidae & Esox lucius & Northern pike & EOLUC & $\mathrm{N}$ & D1 & $\mathrm{A}, \mathrm{B}, \mathrm{C}$ \\
\hline Umbridae & Umbra pygmea & Eastern mudminnow & UMPYG & $\mathrm{E}$ & A & $\mathrm{A}, \mathrm{W}, \mathrm{R}$ \\
\hline Osmeridae & Osmerus eperlanus & Smelt & OSEPE & $\mathrm{N}$ & B & A, B \\
\hline \multirow[t]{3}{*}{ Coregonidae } & Coregonus albula & Vendace & COALB & $\mathrm{N}$ & D2 & $\mathrm{A}, \mathrm{B}, \mathrm{C}$ \\
\hline & Coregonus lavaretus & European whitefish & COLAV & $\mathrm{N}$ & D2 & $\mathrm{A}, \mathrm{C}$ \\
\hline & Coregonus peled & Peled & COPEL & $\mathrm{E}$ & D2 & $\mathrm{A}, \mathrm{B}$ \\
\hline \multirow[t]{5}{*}{ Salmonidae } & Thymalus thymalus & Grayling & THTHY & $\mathrm{N}$ & $\mathrm{C}$ & $\mathrm{A}, \mathrm{B}, \mathrm{C}$ \\
\hline & Hucho hucho & Huchen & HUHUC & $\mathrm{N}$ & $\mathrm{C}$ & $\mathrm{A}, \mathrm{B}, \mathrm{C}, \mathrm{E}$ \\
\hline & Salmo salar & Atlantic salmon & SASAL & $\mathrm{N}$ & $\mathrm{C}$ & $\mathrm{A}, \mathrm{B}, \mathrm{F}$ \\
\hline & Salmo trutta & Sea trout & SATRU & $\mathrm{N}$ & $\mathrm{C}$ & $\mathrm{A}, \mathrm{B}, \mathrm{V}$ \\
\hline & Salmo trutta fario & Brown trout & SAAR & $\mathrm{N}$ & $\mathrm{C}$ & $\mathrm{A}, \mathrm{B}$ \\
\hline
\end{tabular}


Table 1 continued

\begin{tabular}{|c|c|c|c|c|c|c|}
\hline & Scientific name & Common name & Code & Status & Group & References \\
\hline & Oncorhynchus mykiss ${ }^{\mathrm{a}}$ & Rainbow trout & ONMYK & $E^{a}$ & $\mathrm{C}$ & $\mathrm{A}, \mathrm{B}, \mathrm{C}$ \\
\hline Gadidae & Lota lota & Burbot & LOLOT & $\mathrm{N}$ & D1 & $\mathrm{A}, \mathrm{D}, \mathrm{E}, \mathrm{B}$ \\
\hline \multirow[t]{2}{*}{ Gasterosteidae } & Gasterosteus aculeatus & Three-spined stickleback & GAACU & $\mathrm{N}$ & A & $\mathrm{A}, \mathrm{B}, \mathrm{C}$ \\
\hline & Pungitius pungitius & Ninespine stickleback & PUPUN & $\mathrm{N}$ & A & $\mathrm{A}, \mathrm{B}, \mathrm{C}$ \\
\hline \multirow[t]{2}{*}{ Cottidae } & Cottus gobio & European bullhead & COGOB & $\mathrm{N}$ & A & $\mathrm{A}, \mathrm{B}$ \\
\hline & Cottus poecilopus & Siberian sculpin & COPOE & $\mathrm{N}$ & A & A \\
\hline Centrarchidae & Lepomis gibbosus & Pumpkinseed & LEGIB & $\mathrm{E}$ & A & A \\
\hline \multirow[t]{3}{*}{ Percidae } & Perca fluviatilis & Eurasian perch & PEFLU & $\mathrm{N}$ & D2 & A, C, D \\
\hline & Gymnocephalus cernuus & Ruffe & GYCER & $\mathrm{N}$ & D1 & $\mathrm{A}, \mathrm{C}$ \\
\hline & Sander lucioperca & Pikeperch & STLUC & $\mathrm{N}$ & $\mathrm{C}$ & $\mathrm{A}, \mathrm{B}, \mathrm{C}, \mathrm{K}$ \\
\hline Odontobutidae & Perccottus glenii & Amur sleeper & PRGLE & $\mathrm{E}$ & A & $\mathrm{M}, \mathrm{A}$ \\
\hline \multirow[t]{4}{*}{ Gobiidae } & Babka gymnotrachelus & Racer goby & NEGYM & $\mathrm{E}$ & A & $\mathrm{M}, \mathrm{J}$ \\
\hline & Neogobius melanostomus & Round goby & NEMEL & $\mathrm{E}$ & A & M \\
\hline & Neogobius fluviatilis & Monkey goby & NEFLU & $\mathrm{E}$ & A & M \\
\hline & Proterorhinus semilunaris & Western tubenose goby & PRMAR & $\mathrm{E}$ & A & $\mathrm{M}$ \\
\hline
\end{tabular}

Status $\mathrm{N}$-native species, E-exotic

References: A—Brylińska (2000), B—Brylińska (1986), C—Rolik and Rembiszewski (1987), D—Baruš and Oliva (1995), E—Erös (2005), F-Fish Base (www.fishbase.org), S-Szczerbowski and Szczerbowski (1996), G-Záhorská, Kováč (2009); H—Boroń et al. (2002), I-Witkowski et al. (1997), J—Grabowska and Grabowski (2005), K-Craig 2000, M-Miller (2003), N-Novomeská, Kováč (2009), R—Dederen et al. (1986), V—Kamler (1987), W-Hartog and Wendelaar Bonga (1990)

a Does not breed in its naturalized range

\section{Results}

The majority of life-history traits were autocorrelated (Table 2). Among them longevity, age and length at maturation, maximum total body length and fecundity were positively intercorrelated (Table 2). Larval size at hatching showed a strong positive correlation with maximum total body length, length and age of maturity and egg size. Type of spawning was negatively correlated with almost all traits, while it was positively correlated with duration of spawning. Parental investment was negatively correlated with most traits, except egg diameter which was positively correlated.

PC1 and PC2 accounted for $86.4 \%$ of the total variability among life-history traits (Table 3 ), with PC1 accounting for total body length, age at maturity, and maximum absolute fecundity. Egg diameter and larval standard length at hatching were explained by PC2. Based on life-history traits, five discrete clusters of fish species could be distinguished (Fig. 1). These five groups differed significantly in first and second component scores (Table 4). Multiple-comparisons (Tukey-Kramer test) showed that groups A and B were significantly different from the others for traits correlated with PC1, i.e. body size, longevity, maturity, fecundity, and group $\mathrm{C}$ was different from the rest for traits correlated with PC2, i.e. egg diameter and larval length (Fig. 2; Table 4). Separate non-parametric variance analyses of the traits that did not show a lognormal distribution, also displayed significant differences among groups in spawning type $\left(H_{4,59}=28.295\right.$, $p<0.001)$ duration of spawning $\left(H_{4,59}=10.181\right.$, $p<0.05)$ and parental investment $\left(H_{4,59}=56.242\right.$, $p<0.001)$. These traits distinguished two sub-groups, D1 and D2, which differed significantly in duration of breeding season (Fig. 4) and number of spawning events per year. Group D1 included only species that deposited eggs once a year, whereas Group D2 comprised species that were either multi- or single spawners (Fig. 5). Group A was distinguished from the others by parental investment (Fig. 5).

Most non-native invasive species (except for gibel carp Carassius gibelio and peled Coregonus peled) are included in Group A, which consists of 15 species of relatively short maximum body length (except brown bullhead Ameiurus nebulosus and round goby Neogobius melanostomus), short-life span, early maturation (Figs. 1, 2), multiple spawning events (Fig. 3) and an 


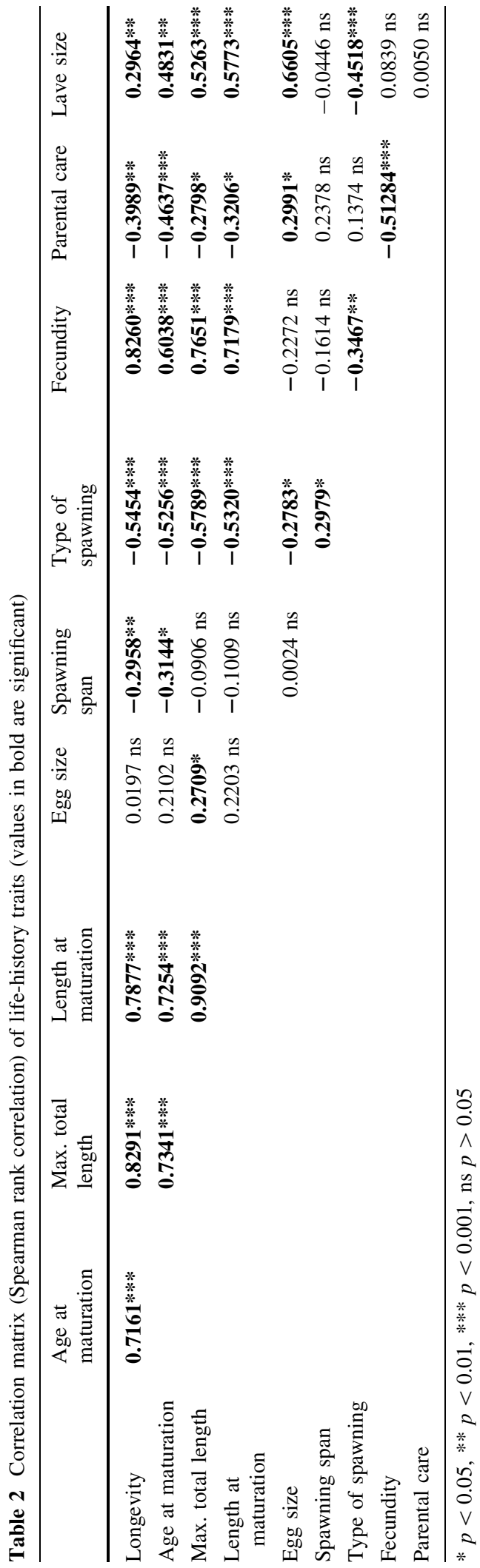

extended breeding season, i.e. longer that those of all other groups except D2 (Fig. 4). Group A species are particularly characterized by parental care: guarders substratum choosers, e.g. sunbleak Leucaspius delineatus and topmouth gudgeon Pseudorasbora parva and guarders-nest spawners e.g. brown bullhead, round goby, monkey goby Neogobius fluviatilis, racer goby Babka gymnotrachelus, western tubenose goby Proterorhinus semilunaris, Amur sleeper Perccottus glenii, pumpkinseed Lepomis gibbosus, Eastern mudminnow Umbra pygmaea, European bullhead Cottus gobio, Alpine bullhead C. peocilopus and ariadnophilous sticklebacks Gasterosteus aculeatus, Pungitius pungitius. This group also included distinctive brood-hiding species-ostracophilous European bitterling Rhodeus amarus (Table 1; Fig. 5). Group B consisted of nine fishes, mostly rheophilous, as well as bottom dwellers associated with a sandy substrate, i.e. spined loach Cobitis taenia, golden loach Sabanejewia aurata, stone loach Barbatula barbatula, gudgeon Gobio gobio, whitefin gudgeon G. albipinnatus, or the open water column, i.e. European minnow Phoxinus phoxinus, spirlin Alburnoides bipunctatus (Table 1; Fig. 1). All of these are small, short-lived fishes with an absolute fecundity higher than that in Group A, spawning twice each season, but displaying no parental care, in contrast to species in Group A (Fig. 5). Group C contains seven large fish species, mainly brood-hiding salmonids (Table 1; Fig. 1) with relatively large eggs and larvae (Fig. 2). This group also included large-bodied species: European catfish Silurus glanis and pikeperch Sander lucioperca (Fig. 1) that guard their eggs (Fig. 5). The highest number of species belongs to groups D1 and D2 (15 and 12 species, respectively). They encompass mainly cyprinids, but also two coregonids, two percids (Eurasian perch Perca fluviatilis, ruffe Gymnocephalus cernuus), burbot Lota lota, northern pike Esox lucius and European eel Anguilla anguilla (Table 1; Fig. 1). These two sub-group species are much more variable in their reproductive styles, considering the duration of spawning and number of spawning events (Figs. 3, 4), but do not exhibit parental care (Fig. 5) and are of medium-to-large maximum body length, late maturation and high maximum fecundity (Fig. 2). The subgroup D1 includes two common non-native fishes (common carp and gibel), whereas intentionally introduced whitefish (C. peled) was classified into Group D2. 
Table 3 Factor loadings of seven life-history traits in Principal Component Analysis (values in bold are significant)

\begin{tabular}{lll}
\hline Life-history traits & PC 1 & PC 2 \\
\hline Longevity & $\mathbf{0 . 8 9 1 * *}$ & -0.215 \\
Age at maturation & $\mathbf{0 . 8 2 6}^{* * * *}$ & -0.146 \\
Maximum total body length & $\mathbf{0 . 9 6 0 * *}$ & 0.068 \\
Total length at maturation & $\mathbf{0 . 9 4 3}^{* *}$ & 0.102 \\
Maximum egg diameter & 0.155 & $\mathbf{0 . 9 2 6} * *$ \\
Maximum absolute fecundity & $\mathbf{0 . 7 9 2} * * *$ & $-0.522^{* * *}$ \\
Larval standard length at hatching & $0.547 * * *$ & $\mathbf{0 . 7 7 2} * * *$ \\
Eigenvalues & 4.238 & 1.809 \\
Explained variance & $\mathbf{6 0 . 5}$ & $\mathbf{2 5 . 8}$ \\
Cumulative explained variance & $\mathbf{6 0 . 5}$ & $\mathbf{8 6 . 4}$ \\
\hline
\end{tabular}

$* * p<0.01, * * * p<0.001$

\section{Discussion}

Our results indicate that the freshwater fish fauna of the Central European biogeographical region comprises five different suites of life-history traits. The majority of native fish species are relatively medium or large, long lived, reproduce at an older age, have high fecundity, scatter their eggs on the substrate and exhibit no post-spawning care of eggs and young stages (groups D1 and D2). They account for ca. $50 \%$ of native fish species found in Polish waters listed by Witkowski et al. (2004), while species characterized by other sets of life-history traits contribute much less (groups A, B, C, respectively: 11.5, 25, 13.5\%.). Domination by groups D1 and D2 is particularly visible in the fish fauna of lowland rivers of Poland, Lithuania and Germany (Table 5). Most species belonging to these groups live in fluvial and lacustrine habitats, avoiding fast-flowing cold waters (Brylińska 2000). The predominance of such large, long-lived, late-maturing species results from the postglacial recolonization history of the Central European biogeographical region. The formation of large periglacial lakes during interglacials and at the end of the Pleistocene enabled migration of species preferring standing or slowly flowing waters (Rolik and Rembiszewski 1987; Mahon 1984; Moyle and Herbold 1987).

The majority of non-native invasive fish species collectively exhibit a contrasting suite of life-history traits compared with native species. They tend to be small or medium in size, short lived, mature early, have rather low fecundity but relatively large eggs, spawn at least twice each year over a protracted reproductive season and, what especially distinguishes them from the all other defined groups, exhibit some form of parental care. All non-native invasive species from Group A are classified according to Balon (1990) as guarders, nest spawners or at least substratum choosers. Our results clearly implicate parental care in their reproductive success. Typically, this care involves protecting the eggs from predators, fanning the eggs to ventilate them, and cleaning the eggs, e.g. removal of fungi. Such complex reproductive behavior is well known for gobiids (Miller 1984), but also occurs in about $20 \%$ of all teleost families (Wootton and Smith 2014). Parental care is a taxonomically widely distributed strategy, however it is more common among freshwater than marine families (Blumer 1982; Wootton and Smith 2014). Considering the 52 native freshwater fish species occuring in Poland, only six exhibit some form of parental care, i.e. pikeperch, three-spined stickleback, nine-spined stickleback, sunbleak, European bullhead and Alpine bullhead. It is believed that parental care evolved in fish as a strategy to enhance the survival of eggs and offspring in variable environments and under high predation pressure (Wooton 1990; Sargent and Gross 1993). The behaviour also appears to be advantageous in the establishment and dispersal phase of an invasion. Moreover, nest defense is accompanied by parental aggression toward intruders (Miller 1984). Aggressive behavior is among the features that confer a competitive edge for invasive species, as observed in other fish assemblages, e.g. North America (Moyle 1986). The introduced round goby appeared to be more aggressive than native sculpins (Cottidae) in the Great Lakes of North America, out-competing native species in the occupation of refuges (Dubs and Corkum 1996) and nest sites, while also predating on the eggs of sculpins (Janssen and Jude 2001). The other successful invader, the gibel carp, is the most widely introduced non-native fish species in Poland and in the whole of Central Europe. Although it does not display parental care, gibel carp do express another unique reproductive tactic of unisexuality. The eggs are activated by the sperm of other cyprinids, permitting the production of progeny (often $100 \%$ female) in the absence of conspecific males (Szczerbowski 2001). As a result, in many European freshwater populations of gibel carp the absence, or at least a low frequency, of males has 
Fig. 1 Cluster analysis (Ward method, Euclidian distance) for 59 fish species occurring in Polish inland waters based on ten lifehistory traits

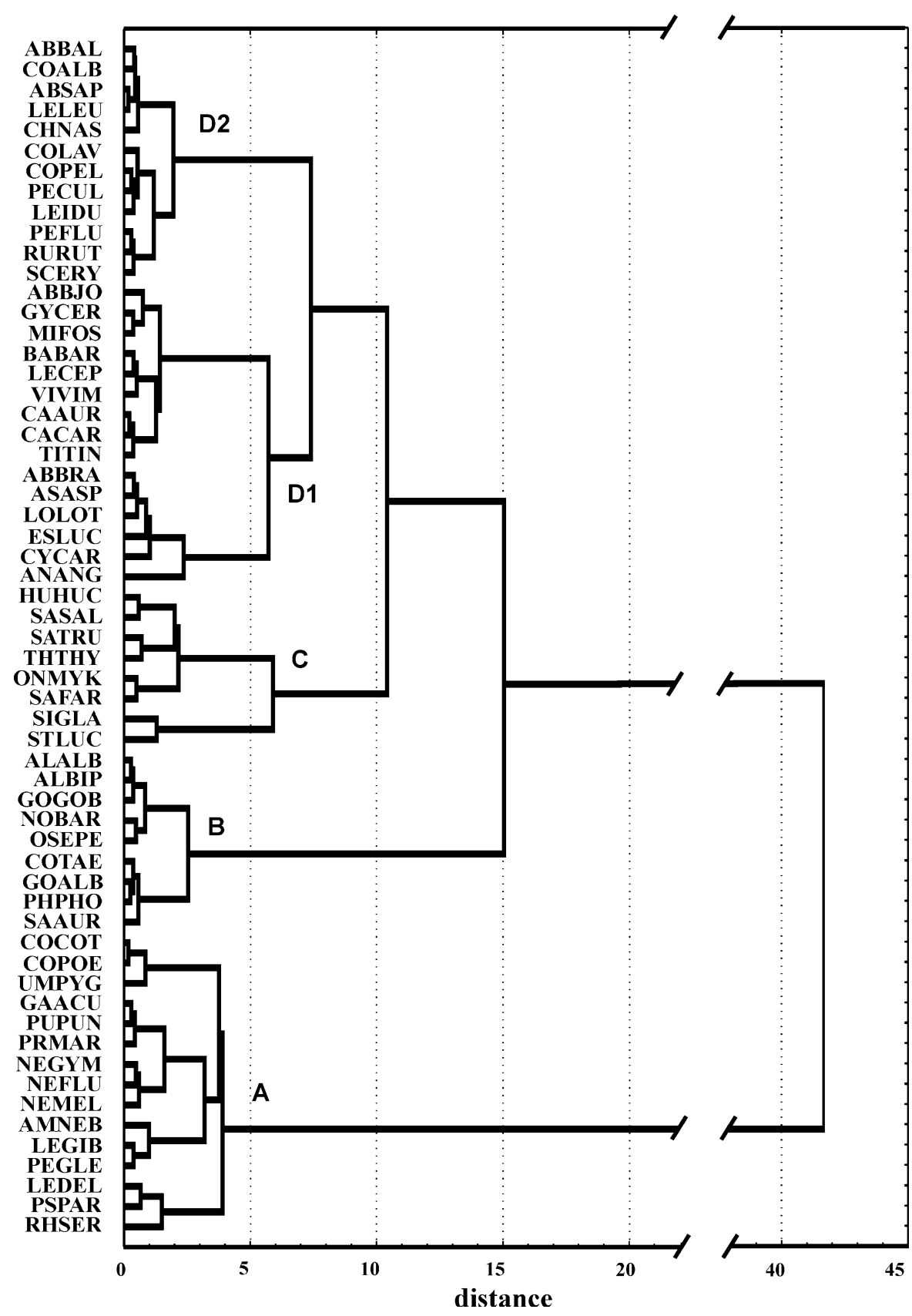

been reported (Holčík and Žitňan 1978; Halačka et al. 2003; Lusková et al. 2004). This mode of reproduction is a form of parthenogenesis. Thus, it is in agreement with the classic portrait of an ideal invader that benefits from asexual reproduction (Ehrlich 1989). Notably, populations of gibel carp with an even sex ratio were found to spread rapidly in brackish water along the Estonian Baltic coastline (Vetemaa et al. 2005). This would suggest that unisexuality is not the only factor contributing to the invasion success of this species.

A successful reproductive strategy is crucial during the establishment stage of an invasion event. In many studies, reproductive traits have been identified as predictors of success or failure during the establishment phase (see Garcia-Berthou 2007 for review), as well as for selection of new species for domestication in aquaculture (Teletchea et al. 2009). In the Central 
Table 4 One-way analysis of variance to test differences between groups (A, B, C, D1 and D2) and Kramer-Tukey post hoc test on the basis of PCA score for continuous life-history variables (underlined groups did not differ significantly)

\begin{tabular}{|c|c|c|c|c|c|c|}
\hline Variable & Source of variation & df & MS & $\mathrm{F}$ & $\mathrm{p}$ & multiple comparisons \\
\hline \multirow[t]{2}{*}{ PC-1 } & between group & 4 & 6.855 & 12.104 & $<0.0001$ & $\begin{array}{lllll}\mathrm{C} & \mathrm{D} 2 & \mathrm{D} 1 & \mathrm{~B} & \mathrm{~A}\end{array}$ \\
\hline & error & 54 & 0.566 & & & \\
\hline \multirow[t]{2}{*}{ PC-2 } & between group & 4 & 3.378 & 4.100 & $<0.01$ & D2 D1 C \\
\hline & error & 54 & 0.824 & & & \\
\hline
\end{tabular}

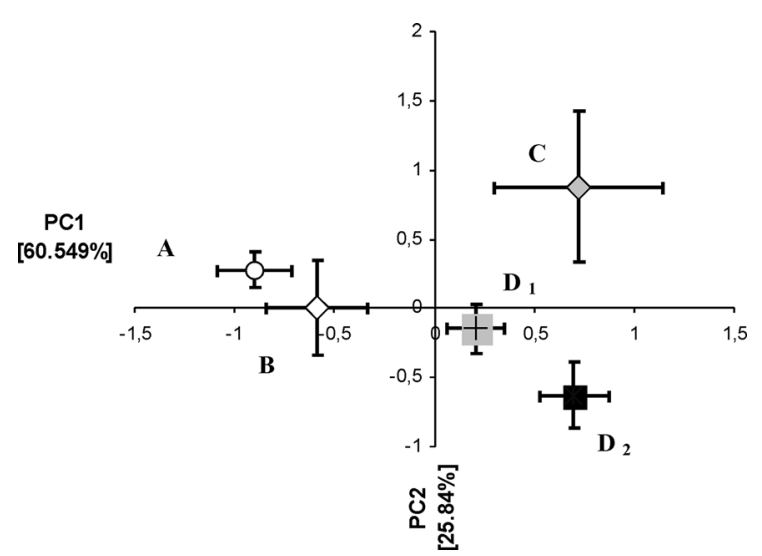

Fig. 2 Principal component scores (mean values and standard errors) of five identified fish species groups based on their seven life-history attributes

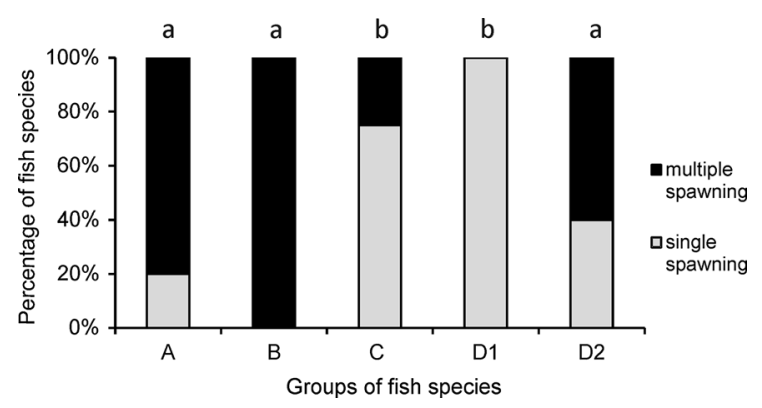

Fig. 3 Percentage of fish species displaying single or multiple spawning types in five identified groups of fish species. Letters above bars denote significantly different groups as determined by post hoc pair-wise comparisons; values with the same letter did not differ significantly

European bioregion, nest spawning and paternal care, or the other 'unusual' reproductive strategies, i.e. unisexuality, may contribute to such 'fitness differences' as suggested by MacDougall et al. (2009). As in the present investigation, parental care was identified as an attribute distinguishing invasive species from natives in Californian streams (Marchetti et al. 2004)

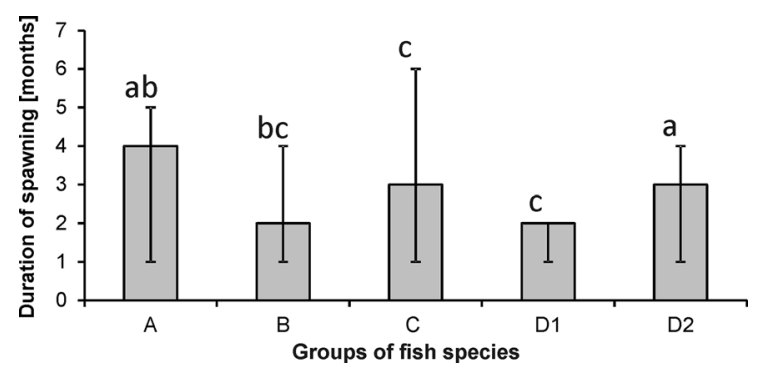

Fig. 4 Modal (bars), minimal and maximal (whiskers) values of spawning duration in five identified groups of fish species. Letters above whiskers bars denote significantly different groups as determined by post hoc pair-wise comparisons; values with the same letter did not differ significantly

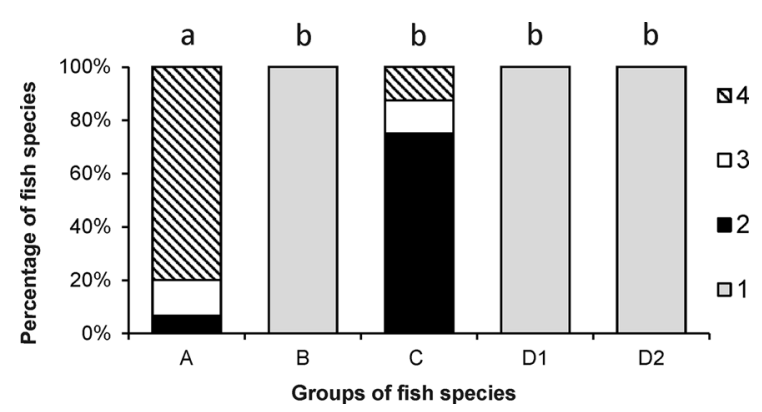

Fig. 5 Percentage of given parental investment categories. (1: non-guarders-open substratum choosers, 2: non-guardersbrood hiders, 3: guarders-substratum choosers, 4: guardersnest spawners) in five identified groups of fish species. Letters above bars denote significantly different groups as determined by post hoc pair-wise comparisons; values with the same letter did not differ significantly

and in the Danube (Erös 2005). A comparison of 29 reproductive traits of freshwater species in Western Europe grouped those that displayed parental care in two closely related clusters (Teletchea et al. 2009); they consisted of almost the same species as those in Group A resulting from our analysis. Finally, it is notable that almost none of the non-native fish species 
Table 5 The percentage share of five suites of life-history traits in the native freshwater fish fauna from selected rivers of the Central European biogeographical region, estimated from lists of recorded species

\begin{tabular}{|c|c|c|c|c|c|c|}
\hline Drainage & River & $\mathrm{A}$ & $\mathrm{B}$ & $\mathrm{C}$ & $\mathrm{D} 1, \mathrm{D} 2$ & References \\
\hline \multirow[t]{3}{*}{ River Vistula } & Lower Vistula & 12 & 16 & 9 & 63 & Wiśniewolski et al. (2001) \\
\hline & River Pilica & 14 & 21 & 10 & 55 & Penczak et al. (2006) \\
\hline & River Bug & 7 & 7 & 26 & 60 & Penczak et al. (2010) \\
\hline \multirow[t]{3}{*}{ River Oder } & Lower Oder & 3 & 20 & 7 & 70 & Wolter and Bischoff (2001) \\
\hline & River Warta & 4 & 18 & 14 & 64 & Kruk et al. (2000) \\
\hline & River Noteć & 19 & 10 & 0 & 71 & Penczak et al. (1999) \\
\hline River Elbe & Lowland waterways & 14 & 17 & 10 & 58 & Wolter (2001) \\
\hline River Neman & Lower and middle River Neman & 6 & 23 & 13 & 58 & Kesminas and Repečka (2005) \\
\hline
\end{tabular}

whose introduction to Polish inland waters was unsuccessful, exhibited parental care (Witkowski 2002; Grabowska et al. 2010). The only exception is the European mudminnow, Umbra krameri, though its presence in Poland is disputable (Grabowska et al. 2010). As a note of caution, unsuccessful, unintentional introductions that have gone unrecorded are not included in this survey. However, some fish species native to the Central European Bioregion sensu Reyjol et al. (2007), despite exhibiting parental care and other life-history traits in common with other successful invaders are vulnerable to extinction, e.g. Cottus gobio and $C$. peocilopus have recently declined in abundance. They have primarily suffered from habitat loss, landscape alteration and pollution, but they may also be out-competed by more aggressive non-native species (Kakareko et al. 2013; Jermacz et al. 2014).

Furthermore, all species that have established selfsustaining populations in Central European inland waters are known to have other relevant characteristics, usually attributed to successful fish invaders (Garcia-Berthou 2007). A broad diet, as well as an opportunistic feeding strategy were found in the racer goby, monkey goby, round goby and Amur sleeper in the invaded waters of Central European waters (Kostrzewa and Grabowski 2003; Grabowska and Grabowski 2005; Kakareko et al. 2005; Borza and Eros 2009; Grabowska et al. 2009a, b; Polačik et al. 2009; Brandner et al. 2013a). High environmental tolerance also characterizes most of these species, e.g. Ponto-Caspian gobiids are oligoeurohaline (Miller 2003), and show tolerance for a wide range of salinities; gibel carp, topmouth gudgeon, brown bullhead and Amur sleeper have low oxygen demands
(Fry 1971; Bogutskaya and Naseka 2002). The last species is also known to survive in extremely harsh conditions, e.g. it is able to freeze and then 'defrost'. It also survives warming and drying of water bodies and has a greater tolerance of poor water quality than most other fish species (Bogutskaya and Naseka 2002). The topmouth gudgeon appears unresponsive to otherwise lethal concentrations of rotenone and to longer exposure times than native species in Great Britain (Allen et al. 2006). The peled is reported to have lower oxygen and temperature demands than coregonids native to Polish lakes (Szczerbowski 2000). The features highlighted above also differentiate nonnative species from less tolerant native fish species and in some environments allows them to outcompete the natives.

There are no universal life-history traits that can be used as reliable predictors of the success or failure of invasion by fish species. In contrast to our findings, Vila-Gispert et al. (2005) compared life-history traits of native and invasive fish species in small Catalonian streams and obtained a completely different suite of traits that characterized successful invasion. Most of the exotic species were characterized by large body size, long life span, late maturity, high fecundity, limited spawning events each year, and a short breeding season, whereas indigenous species had the opposite life-history traits. However, in this case the life-history strategy was not a primary determinant of invasive success and the differences detected between invasive and native fishes resulted rather from adaption to local conditions in which they originally evolved. The exotic species in these cases took advantage of 'novel niche opportunity' sensu Shea 
and Chesson (2002), such as anthropogenic alteration of flow regimes. For example, damming created new habitats where the non-natives appeared to be better adapted than natives, which additionally suffered from a deterioration in water quality. These findings suggest that a combination of 'niche opportunity' and 'fitness difference' sensu MacDougall et al. (2009) can better explain invasive success than the suite of life-history traits itself (MacDougall et al. 2009). Similarly, comparison of native versus exotic fish species in the River Colorado basin (Olden et al. 2006) provided support for the importance of both components of invasive species success, i.e. 'niche opportunity' and difference in life-history traits.

To conclude, in spite of varied origins, taxonomy, mode of arrival, vectors and pathways of dispersal the group of non-indigenous invasive fish species occurring in Poland appeared to share life-history traits and certain other biological attributes. Moreover, this suite of life-history traits differentiated them from the majority of native freshwater species of the Central European biogeographical region. These findings support the theory that diverging in at least one biological attribute (assuming that this difference increases competitive superiority) is essential to invasion success. Invasion by most of the non-native species in our study did not appear to be facilitated by high human-mediated propagule pressure, as happens in the case of commercial fish species, which are typically intentionally introduced several times into many localities. Successful reproductive tactics, diet breadth and environmental tolerance combine to create a high invasive potential for the exotic species that have established in Poland and other Central European countries. This combination of attributes seem to be especially advantageous since the species listed as naturalized non-natives in Poland are the most widespread invasive fishes in Europe (Copp et al. 2005). Top mouth gudgeon have expanded to almost all European countries except for Scandinavia, also reaching northern Africa (Gozlan et al. 2010). Gibel carp, brown bullhead and pumpkinseed are also widely distributed in Europe, and the Ponto-Caspian gobies are still expanding their range, not only in the Vistula drainage (Grabowska et al. 2008), but also throughout the Danube system and to Western Europe through the Main-Danube Canal (Copp et al. 2005; Roche et al. 2013). The Amur sleeper have invaded the whole of Russia, Central Europe, and the Balkans
(Bogutskaya and Naseka 2002) and recently also Germany (Reshetnikov and Schliewen 2013). It is inevitable that the range expansions of these species will continue in Europe and beyond.

Acknowledgments We thank G.H. Copp for comments and suggestions to an earlier version of the manuscript as well as Carl Smith for language corrections. Our research was supported by a Grant of the Polish Ministry of Science and Higher Education. No. N N304 371539.

Open Access This article is distributed under the terms of the Creative Commons Attribution License which permits any use, distribution, and reproduction in any medium, provided the original author(s) and the source are credited.

\section{References}

Alcaraz C, Vila-Gispert A, García-Berthou E (2005) Profiling invasive fish species: the importance of phylogeny and human use. Divers Distrib 11:289-298

Allen Y, Kirby S, Copp GH, Brazier M (2006) Toxicity of rotenone to topmouth gudgeon Pseudorasbora parva for eradication of this non-native species from a tarn in Cumbria, England. Fish Manag Ecol 13:337-340

Balon EK (1990) Epigenesis of an epigeneticist: the development of some alternative concepts on early ontogeny and evolution of fishes. Guelph Ichthyol Rev 1:1-48

Bănărescu P (1990) Zoogeography of fresh waters. Distribution and Dispersal of Freshwater Animals in North America and Eurasia, AULA-Verlag

Baruš V, Oliva O (1995) Michulovci petromyzontes a ryby osteichthyes. Academia, Praha

Blank A, Tedesco PA, Lamouroux N (2007) Relationships between life-history strategies of European freshwater fish species and their habitat. Freshw Biol 52:843-859

Blumer LS (1982) A bibliography and categorization of bony fishes exhibiting parental care. Zool J Linn Soc-Lond 76:1122

Bogutskaya NG, Naseka AM (2002) Perccottus glenii Dybowski, 1877. Freshwater Fishes of Russia, Zoological Institute RAS. INTERNET: http://www.zin.ru/Animalia/ Pisces/eng/taxbase_e/species_e/perccottus/perccottus_e. htm

Bøhn T, Sandlund OT, Amundsen PA, Primicerio R (2004) Rapid changing life history during invasion. Oikos 106:138-150

Boroń A, Kotusz J, Przybylski M (2002) Koza, koza złotawa, piskorz, śliz [Spined loach, golden loach, weather loach, stone loach]. Wydawnictwo IRS, Olsztyn

Borza P, Erős Oertel N (2009) Food resource partitioning between two invasive gobiid species (Pisces, Gobiidae) in the littoral zone of the River Danube, Hungary. Int Rev Hydrobiol 94:609-621

Brandner J, Auerswald K, Cerwenka AF, Schliewen UK, Geist J (2013a) Comparative feeding ecology of invasive PontoCaspian Gobies. Hydrobiologia 703:113-131 
Brandner J, Cerwenka AF, Schliewen UK, Geist J (2013b) Bigger is better: characteristics of round gobies forming an invasion front in the danube river. PLoS ONE 8(9):e73036

Britton JR, Davies GD, Brazier M (2008) Contrasting life history traits of invasive topmouth gudgeon (Pseudorasbora parva) in adjacent ponds in England. J Appl Ichthyol 24:694-698

Brown JH (1989) Patterns, modes and extents of invasions by vertebrates. In: Drake JA, Mooney HA, di Castri F, Groves RH, Kruger FJ, Rejmánek M, Williamson M (eds) Biological invasions: a global perspective. SCOPE 37. Wiley, New York, pp 85-109

Brylińska M (1986) Ryby słodkowodne Polski [Frashwater Fishes of Poland]. Wydawnictwo Naukowe PWN

Brylińska M (2000) Ryby słodkowodne Polski [Frashwater Fishes of Poland]. Wydawnictwo Naukowe PWN

Callaway RM, Ridenour WM (2004) Novel weapons: invasive success and the evolution of increased competitive ability. Front Ecol Environ 2:436-443

Casal CMV (2006) Global documentation of fish introductions: the growing crisis and recommendations for action. Biol Invasions 8:3-11

Copp GH, Bianco PG, Bogutskaya N, Erős T, Falka I, Ferreira MT, Fox MG, Freyhof J, Gozlan RE, Grabowska J, Kováč $\mathrm{V}$, Moreno-Amich R, Naseka AM, Peňáz M, Povž M, Przybylski M, Robillard M, Russell IC, Stakenas S, Šumer S, Vila-Gispert A, Wiesner C (2005) To be, or not to be, a non-native freshwater fish? J Appl Ichthyol 21:242-262

Craig JF (2000) Percid fishes: systematics, ecology and exploitation. Blackwell, Oxford

Deahler CC (2003) Performance comparisons of co-occuring native and alien plants: implications for conservation. Annu Rev Ecol Evol Syst 34:183-211

Dederen LHT, Leuven RSEW, Wendelaar SE, Oyen FGF (1986) Biology of the acid-tolerant fish species Umbra pygmaea (De Kay, 1842). J Fish Biol 28:307-326

Dubs DOL, Corkum LD (1996) Behavioral interactions between round gobies (Neogobius melanostomus) and mottled sculpins (Cottus bairdi). J Great Lakes Res 22:838-844

Ehrlich PR (1989) Attributes of invaders and the invading processes: vertebrates. In: Drake JA, Mooney HA, di Castri F, Groves RH, Kruger FJ, Rejmánek M, Williamson M (eds) Biological invasions: a global perspective SCOPE 37. Wiley, New York, pp 315-328

Erős T (2005) Life-history diversification in the Middle Danubian fish fauna- a conservation perspective. Arch Hydrobiol (Suppl 158, Large Rivers) 16:289-304

Fox MG, Vila-Gispert A, Copp GH (2007) Life-history traits of introduced iberian pumpkinseed Lepomis gibbosus relative to native populations. Can differences explain colonization success? J Fish Biol 71(Suppl. D):56-69

Fry FEJ (1971) The effect of environmental factors on the physiology of fish. In: Hoar WS, Randall DJ (eds) Fish physiology, vol 6. Academic Press, New York, pp 1-98

Garcia-Berthou E (2007) The characteristics of invasive fishes: what has been learned so far? J Fish Biol 71(Suppl. D):33-35

Gozlan RE, Andreou D, Asaeda T, Beyer K, Bouhadad R, Burnard D, Caiola N, Cakic P, Djikanovic V, Esmaeili HR, Falka I, Golicher D, Harka A, Jeney G, Kováč V, Musil J, Nocita A, Povz M, Poulet N, Virbickas T, Wolter C, Tarkan
AS, Tricarico E, Trichkova T, Verreycken H, Witkowski A, Zhang CG, Zweimueller I, Britton JR (2010) Pan-continental invasion of Pseudorasbora parva: towards a better understanding of freshwater fish invasions. Fish Fish $11: 315-340$

Grabowska J, Grabowski M (2005) Diel-feeding activity in early summer of racer goby Neogobius gymnotrachelus (Gobiidae): a new invader in the Baltic basin. J Appl Ichthyol 21:282-286

Grabowska J, Pietraszewski D, Ondračková M (2008) Tubenose goby Proterorhinus marmoratus (Pallas, 1814) has joined three other Ponto-Caspian gobies in the Vistula River (Poland). Aquat Invasions 3:261-265

Grabowska J, Grabowski M, Kostecka A (2009a) Diet and feeding habits of monkey goby (Neogobius fluviatilis) in a newly invaded area. Biol Invasions 11:2161-2170

Grabowska J, Grabowski M, Pietraszewski D, Gmur J (2009b) Non-selective predator-versatile diet of Amur sleeper (Perccottus glenii Dybowski, 1877) in the Vistula River (Poland), a newly invaded ecosystem. J Appl Ichthyol 25:451-459

Grabowska J, Witkowski A, Kotusz J (2010) Alien invasive fish species in polish waters: an overview. Folia Zool 59(1):73-85

Halačka K, Lusková V, Lusk S (2003) Carassius "gibelio" in the fish communities of the Czech Republic. Ecohydrol Hydrobiol 3:133-138

Hartog C, Wendelaar Bonga SE (1990) Umbra pygmaea, an acid-tolerant fish. Naturwissenschaften 77:40-41

Hewitt GM (2004) Genetic consequences of climatic oscillations in the Quaternary. Phil Trans R Soc Lond B 359:183-195

Holčík J, Žitňan R (1978) On the expansion and origin of Carassius auratus in Czechoslovakia. Folia Zool 27:279-288

Janssen J, Jude DJ (2001) Recruitment failure of mottled sculpin Cottus bairdi in Calumet Harbor, southern Lake Michigan, induced by the newly introduced round goby Neogobius melanostomus. J Great Lakes Res 27:319-328

Jermacz Ł, Kobak J, Dzierżyńska A, Kakareko T (2014) The effect of flow on the competition between the alien racer goby and native European bullhead. Ecol Freshw Fish (early view). doi:10.1111/eff.12162

Jeschke JM, Gómez Aparicio A, Haider S, Heger T, Lortie CJ, Pyšek P, Strayer DL (2012) Support for major hypotheses in invasion biology is uneven and declining. NeoBiota $14: 1-20$

Kakareko T, Żbikowski J, Żytkowicz J (2005) Diel partitioning in summer of two syntopic neogobiids from two different habitats of the lower Vistula River, Poland. J Appl Ichthyol 21:292-295

Kakareko T, Kobak J, Grabowska J, Jermacz Ł, Przybylski M, Poznańska M, Pietraszewski D, Copp GH (2013) Competitive interactions for food resources between invasive racer goby Babka gymnotrachelus and native European bullhead Cottus gobio. Biol Invasions 15(11):6519-6533

Kamler E (1987) Comparison of energy contents in spawn of sea trout (Salmo trutta L.) from Rega, Słupia, Wieprza and Vistula Rivers. Pol Arch Hydrobiol 34:245-254

Kesminas V, Repečka R (2005) Human impact on fish assemblages in the Nemunas River, Lithuania. Large Rivers 15 Arch Hydrobiol Suppl 155(1-4):275-287 
Kolar CS, Lodge DM (2001) Progress in invasion biology; predicting invaders. Trends Ecol Evol 16:199-204

Kolar CS, Lodge DM (2002) Ecological predictions and risk assessment for alien fishes in North America. Science 5596:1233-1235

Kostrzewa J, Grabowski M (2003) Oportunistic feeding strategy as factor promoting the expansion of racer goby (Neogobius gymnotrachelus Kessler, 1857) in the Vistula basin. Lauterbornia 48:91-100

Kováč V, Copp GH, Sousa RP (2009) Life-history traits of invasive bighead goby Neogobius kessleri (Günther, 1861) from the middle Danube River, with a reflection on which goby species may win the competition. J Appl Ichthyol 25:33-37

Kruk A, Penczak T, Galicka W, Koszaliński H, Tłoczek K, Kostrzewa J, Marszał L (2000) Ichtiofauna rzeki Warty. [Fish fauna of the Warta River]. Rocz Nauk PZW 13:35-67

Kryzhanovskii SG (1949) Eco-morphological principles and patterns of development among minnow, loach and catfish. Part II ecological groups of fishes and patterns of their distribution. Fish Res Board Can 1:237-331

Lusková V, Halačka K, Vetešník L, Lusk S (2004) Changes of ploidy and sexuality status of 'Carassius auratus' population in the drainage area of the River Dyje (Czech Republic). Ecohydrol Hydrobiol 4:165-171

MacArthur RH, Wilson EO (1967) The theory of Island biogeography. Princeton University Press, Princeton

MacDougall AS, Gilbert B, Levine JM (2009) Plant invasions and the niche. J Ecol 97:609-615

Mahon R (1984) Divergent structure in fish taxocens of north temperate streams. Can J Fish Aquat Sci 41:330-350

Marchetti MP, Moyle PB, Levine R (2004) Alien fishes in California watersheds: characteristics of successful and failed invaders. Ecol Appl 14:587-596

Miller PJ (1984) Tokology of gobies. In: Potts GW, Wootton RJ (eds) Fish reproduction. Academic Press Ltd, London, pp 119-153

Miller PJ (2003) The Freshwater Fishes of Europe. Mugilidae, Atherinidae, Atherinopsidae, Blenidae, Odontobutidae, Gobiidae 1. AULA-Verlag, Wiebelsheim

Moyle PB (1986) Fish introductions into North America: patterns and ecological impact. In: Mooney HA, Drake JA (eds) Ecology of biological invasions of North America and Hawaii. Springer-Verlag, New York, pp 27-43

Moyle PB, Herbold B (1987) Life-history patterns and community structure in stream fishes of western North America: comparisons with eastern North America and Europe. In: Matthews WJ, Heins DC (eds) Community and evolutionary ecology of North American stream fishes. University of Oklahoma Press, Norman, pp 25-32

Moyle PB, Light T (1996) Biological invasions of freshwater: empirical rules and assembly theory. Biol Conserv 78:149-161

Novomeská A, Kováč V (2009) Life-history traits of non-native black bullhead Ameiurus melas with comments on its invasive potential. J Appl Ichthyol 25:75-84

Olden JD, LeRoy Poff N, Bestgen KR (2006) Life-history strategies predict fish invasions and extripations in the Colorado River Basin. Ecol Monogr 76:5-40

Penczak T, Kostrzewa J, Marszał L, Koszaliński H, Kruk A (1999) Ichtiofauna rzeki Noteć. [Fish fauna of the Notec River]. Roczniki Naukowe PZW 12:81-94
Penczak T, Kruk A, Zięba G, Marszał L, Koszaliński H, Tybulczuk S, Galicka W (2006) Ichtiofauna dorzecza Pilicy w piątej dekadzie badań. Cześć I. Pilica. [Fish fauna in the Pilica River system in the fifth decade of study. Part I. Pilica River]. Roczniki Naukowe PZW 19:103-122

Penczak T, Kruk A, Galicka W, Tybulczuk S, Marszal L, Pietraszewski D, Tszydel M (2010) Ichtiofauna Bugu. [Fish fauna of the Bug River]. Roczniki Naukowe PZW 23: $5-24$

Polačik M, Janáč M, Jurajda P, Adámek Z, Ondračková M, Trichkova T, Vassilev M (2009) Invasive gobies in the Danube: invasion success facilitated by availability and selection of superior food resources. Ecol Freshw Fish 18:640-649

Reshetnikov AN, Schliewen UK (2013) First record of the invasive alien fish rotan Perccottus glenii Dybowski, 1877 (Odontobutidae) in the Upper Danube drainage (Bavaria, Germany). J Appl Ichthyol 29:1367-1369

Reyjol Y, Hugueny B, Pont D, Bianco PG, Beier U, Caiola N, Casal F, Cowx I, Economou A, Ferreira T, Hidvogl G, Noble R, Sostoa A, Vigneron T, Virbickas T (2007) Patterns in species richness and endemism of European freshwater fish. Global Ecol Biogeogr 16:65-75

Reynolds JD, Webb TJ, Hawkins LA (2005) Life history and ecological correlates of extinction risk in European freshwater fishes. Can J Fish Aquat Sci 62:854-862

Ribeiro F, Elvira B, Collares-Pereira MJ, Mole PB (2007) Lifehistory traits of on-native fishes in Iberian watersheds across several invasion stages: a first approach. Biol Invasions 10:89-102

Roche KF, Janač M, Jurajda P (2013) A review of Gobiid expansion along the Danube-Rhine corridor-geopolitical change as a driver for invasion. Knowl Manag Aquat Ec 411:01

Rolik H, Rembiszewski JM (1987) Ryby i krągłouste [Pisces et Cyclostomata]. Państwowe Wydawnictwo Naukowe, Warszawa

Sakai AK, Allendorf FW, Holt JS, Lodge DM, Molofsky J, With KA, Baughman S, Cabin RJ, Cohen JE, Ellstrand NC, McCauley DE, O’Neil P, Parker IM, Thompson JN, Weller SG (2001) The population biology of invasive species. Annu Rev Ecol Syst 32:305-332

Sargent RC, Gross MR (1993) Williams' principle: an explanation of parental care in teleost fishes. In: Pitcher TJ (ed) Behaviour of Teleost Fishes, 2nd edn. Chapman \& Hall, London, pp 333-361

Shea K, Chesson P (2002) Community ecology theory as a framework for biological invasions. Trends Ecol Evol 17(4):170-176

StatSoft Inc (2001) STATISTICA (data analysis software system), version 6.0. www.statsoft.com

Szczerbowski J (2000) Peluga [Peled] Coregonus peled Gmelin, 1788. In: Brylińska M (ed) Ryby słodkowodne Polski [Freshwater Fishes of Poland]. Wydawnictwo Naukowe PWN, Warszawa, pp 386-389

Szczerbowski JA (2001) Carassius auratus (Linneaus, 1758). In: Banarescu PM, Paepke HJ (eds) The freshwater fishes of Europe, 5/III Cyprinidae 2. Part III, Carassius to Cyprinus Gasterosteidae. AULA-Verlag, pp 5-41

Szczerbowski JA, Szczerbowski A (1996) Karasie [Carassius sp.] Wydawnictwo IRS, Olsztyn 
Teletchea F, Fostier A, Kamler E, Gardeur JN, Le Bail PY, Jalabert B, Fontaine P (2009) Comparative analysis of reproductive traits in 65 freshwater fish species: application to the domestication of new fish species. Rev Fish Biol Fisher 19:403-430

Valiente AM, Juanes F, Núñez P, García-Vásquez E (2010) Brown trout (Salmo trutta) invasiveness: plasticity in life history is more important than genetic variability. Biol Invasions 12:451-462

Vetemaa M, Eschbaum R, Albert A, Saat T (2005) Distribution, sex ratio and growth of Carassius gibelio (Bloch) in coastal and inland waters of Estonia (north-eastern Baltic Sea). J Appl Ichthyol 21:287-291

Vila-Gispert A, Alcaraz C, Garcia-Berthou E (2005) Life-history traits of invasive fish in small Mediterranean streams. Biol Invasions 7:107-116

Villeneuve F, Copp GH, Fox MG, Stakenas S (2005) Interpopulation variation in growth and life-history traits of the introduced sunfish, pumpkinseed Lepomis gibbosus, in southern England. J Appl Ichthyol 21:275-281

Williamson M (1996) Biological invasions. Chapman \& Hall, London

Williamson M (1999) Invasions. Ecography 22:5-12

Winemiller KO, Rose KA (1992) Patterns of life-history diversification in North American fishes: implications for population regulation. Can J Fish Aquat Sci 49:2196-2218

Witkowski A (2002) Introduction of fishes into Poland: benefaction or plague? Nat Conserv 59:41-52

Witkowski A, Grabowska J (2012) The non-indigenous freshwater fishes of Poland: threats for native ichthyofauna and consequence for fishery: A review. Acta Ichthyol Piscat 42:77-87

Witkowski A, Cieśla M, Napora K (1997) Jaź [Ide]. Wydawnictwo IRS, Olsztyn

Witkowski A, Kotusz J, Przybylski M, Marszał L, Heese T, Amirowicz A, Buras P, Kukuła K (2004) Pochodzenie, skład gatunkowy i aktualny stopień zagrożenia ichtiofauny w dorzeczu Wisły i Odry [Origin, species composition and present degree of threat to fish fauna in the Vistula and Oder River systems]. Arch Pol Fish 12:7-20

Wolter C (2001) Conservation of fish species diversity in navigable waterways. Landsc Urban Plan 53:135-144

Wolter C, Bischoff A (2001) Seasonal changes of fish diversity in the main channel of the large lowland River Oder. Regul Rivers Res Mgmt 17:595-608

Wooton RJ (1990) Ecology of teleost fishes. Chapman and Hall, London

Wootton RJ, Smith C (2014) Reproductive biology of teleost fishes. Wiley-Blackwell, Oxford

Záhorská E, Kováč V (2009) Reproductive parameters of invasive topmouth gudgeon Pseudorasbora parva (Temminck and Schlegel, 1846) from Slovakia. J Appl Ichthyol 25:466-469

Záhorská E, Kováč V (2013) Environmentally induced shift in reproductive traits of a long-term established population of topmouth gudgeon (Pseudorasbora parva). J Appl Ichthyol 29:218-220 